\title{
Overexpression of retinoblastoma-binding protein 4 contributes to the radiosensitivity of AGS gastric cancer cells via phosphoinositide3-kinase/protein kinase B pathway suppression
}

\author{
XIAOXI JIN ${ }^{1}$, RUI JIANG ${ }^{2}$, YONGSHENG XIANG ${ }^{2}$, ZHEN FAN ${ }^{2}$, ZHIWEI WU ${ }^{2}$, \\ BO YANG ${ }^{2}$, LUJUN YANG ${ }^{2}$, SHANSHAN WEI ${ }^{2}$ and YAN YANG ${ }^{1}$ \\ ${ }^{1}$ Laboratory Department; ${ }^{2}$ Department of Hematology, Jingmen No. 1 People's Hospital, Jingmen, Hubei 448000, P.R. China
}

Received December 27, 2017; Accepted May 4, 2018

DOI: $10.3892 / \mathrm{mmr} .2018 .9153$

\begin{abstract}
In the present study, the effects and underlying mechanism of RbAp48 on the radiosensitivity of AGS gastric cancer cells was investigated. Cell proliferation was determined with an MTT assay. Flow cytometry was performed to evaluate the cell cycle and apoptosis. Reverse transcription-quantitative polymerase chain reaction and western blot analysis were performed to detect mRNA and protein expression, respectively, including RbAp48, phosphoinositide 3-kinase (PI3K) and protein kinase $\mathrm{B}(\mathrm{Akt})$. The results revealed that radiation enhanced the expression level of RbAp48 in AGS cells, and that RbAp48 combined with radiation reduced AGS cell proliferation. In addition, $\mathrm{RbAp} 48$ combined with radiation resulted in $G_{2}$ phase arrest and induced apoptosis via regulation of the PI3K/Akt pathway. In conclusion, it was demonstrated that overexpression of RbAp48 enhanced the radiosensitivity of AGS gastric cancer cells via suppression of PI3K/Akt pathway activity, suggesting that RbAp48 may hold potential as a gene therapeutic strategy in the future, aiding in the treatment of gastric cancer.
\end{abstract}

\section{Introduction}

Gastric cancer is one of the most common malignant tumors worldwide. A number of factors contribute to the development of gastric cancer, of which the pathogenesis is highly complex $(1,2)$. Helicobacter pylori infection is listed as a class I carcinogenic factor for gastric cancer by the World Health Organization, and high salt and high nitrate diets may also be risk factors for gastric cancer development (3). Genetic factors, environmental factors and bacterial infections

Correspondence to: Dr Yan Yang, Laboratory Department, Jingmen No. 1 People's Hospital, 67 Xiangshan Avenue, Jingmen, Hubei 448000, P.R. China

E-mail: yanyang495yy@163.com

Key words: retinoblastoma-binding protein 4, radiosensitivity, AGS, gastric cancer, phosphoinositide3-kinase, protein kinase B ultimately affect the occurrence and progression of gastric cancer $(4,5)$. It has been reported that although gastric cancer treatment and prognosis has greatly improved in China, the incidence of gastric cancer remains high (6). As there is a lack of knowledge of specific symptoms, the diagnosis of gastric cancer at an early stage is difficult. Gastrectomy is a widely used strategy in gastric cancer therapy. However, the prognosis of patients with gastric cancer at advanced stages is unsatisfactory (7). Therefore, a better understanding of the occurrence and progression of gastric cancer is of scientific significance.

The primary target molecule of radiotherapy is DNA. The mechanism of cell DNA damage repair is initiated by radiation exposure, which activates cell cycle arrest, thereby promoting repair of injury (8). If DNA fails to repair, it may result in cell death, necrosis or senescence (8). DNA strand breaks (DSBs) induced by radiation exposure are closely associated with cell death. DSB repair is associated with radiosensitivity (9). The effectiveness of therapy of gastric cancer primarily depends on the sensitivity of the tumor to radiotherapy (10-12). Radiation resistance has become key to further deterioration of tumors, thus the study of radiosensitization has become more prevalent.

Gene therapy is being increasingly recognized in tumor therapy. Tumor radiosensitivity is associated with its internal molecular biological mechanism. It has been demonstrated that the abnormal expression of a number of oncogenes and tumor suppressor genes may affect tumor cell apoptosis, radiosensitivity and patient prognosis (13). The potential combination of tumor gene therapy and radiotherapy has therefore been suggested, to ultimately reduce normal tissue damage and enhance the effects of radiotherapy (14). Numerous tumor gene therapies have been investigated in vitro experiments and have exhibited beneficial effects, such as cellular tumor antigen p53 (P53), which has successful results in clinical trials, achieving desirable treatment outcomes (15-17). Retinoblastoma-binding protein 4 ( $\mathrm{RbAp} 48$ ) is a member of the WD-40 protein family and was originally identified as a retinoblastoma protein $(\mathrm{Rb})$ binding protein (18). E2F transcription factor (E2F) 1 and $\mathrm{RbAp} 48$ interaction is mediated by $\mathrm{Rb}$ and histone deacetylase (HDAC) and results in the inhibition of E2F regulatory gene transcription, which are important cell cycle regulatory proteins (19). 
The underlying mechanisms of gastric cancer radiosensitivity remain unclear. The present study aimed to investigate the effect and underlying mechanisms of RbAp48 on gastric cancer cell radiosensitivity.

\section{Materials and methods}

Cell culture. The human gastric cancer cell line (AGS) was purchased from Shanghai Gefan Biotechnology Co., Ltd. (Shanghai, China). The cells were maintained in RPMI-1640 medium (Thermo Fisher Scientific, Inc., Waltham, MA, USA) supplemented with $10 \%$ fetal bovine serum (Gibco; Thermo Fisher Scientific, Inc.) in a $37^{\circ} \mathrm{C}$ incubator with $5 \% \mathrm{CO}_{2}$.

Cell transfection and grouping. pcDNA3.1, pcDNA3.1-RbAp48, RbAp48 siRNA and non-specific scrambled siRNA vectors were obtained from Invitrogen (Thermo Fisher Scientific, Inc.). The vectors were transfected at a final concentration of $100 \mathrm{nmol} / 1$ transfection (20). AGS cells were transfected with pcDNA3.1 (mock), pcDNA3.1-RbAp48 (RbAp48), RbAp48 siRNA (si-RbAp48; 5'-CAGGGCATA CGGCAGTAGT-3') and non-specific scrambled siRNA (NC; 5'-ACGUGACACGUUCGGAGAATT-3') vectors using EndoFectin $^{\mathrm{TM}}$ Max transfection reagent (GeneCopoeia, Inc., Rockville, MD, USA) at $37^{\circ} \mathrm{C}$ for $48 \mathrm{~h}$. Following transfection, cells were lysed for western blot analysis and RT-qPCR to verify transfection efficiency.

There were five AGS cell treatment groups: Control (treated with PBS), mock (treated with pcDNA3.1), control+RAD (treated with 6 Gy radiation), mock+RAD (treated with pcDNA3.1 and radiation), and the RbAp48+RAD group (treated with pcDNA3.1-RbAp48 and radiation), in the early stage of the experiment. There were seven treatment groups in the advanced stage of the experiment, including: pcDNA3.1 (Mock), pcDNA3.1 and 6 Gy radiation (RAD), si-RbAp48, si-RbAp48+RAD, pcDNA3.1-RbAp48 (RbAp48), pcDNA3.1-RbAp48 and radiation (RbAp48+RAD), as well as pcDNA3.1-RbAp48, 6 Gy radiation and $50 \mathrm{ng} / \mathrm{ml}$ insulin-like grow th factor-1 (IGF-1) (RbAp48+RAD+IGF-1). IGF-1 was used as an agonist of the phosphoinositide 3-kinase $(\mathrm{PI} 3 \mathrm{~K}) /$ protein kinase $\mathrm{B}$ (Akt) pathway, and was used to treat cells at $37^{\circ} \mathrm{C}$ for $48 \mathrm{~h}$.

Cell radiation. Cells were digested with $0.25 \%$ trypsin and counted with a hemocytometer prior to radiation exposure. Cells were subsequently transferred into new culture bottles, each containing $10^{6}$ cells. Cells were maintained in the incubator overnight at $37^{\circ} \mathrm{C}$ with $5 \% \mathrm{CO}_{2}$. Following this, cells were treated with $0,2,4$, and $6 \mathrm{~Gy} 6 \mathrm{MV}-\mathrm{X}$ ray at room temperature for $3 \mathrm{~h}$ using a PRIMUS ${ }^{\mathrm{TM}}$ linear accelerator (Siemens AG, Munich, Germany). This was a preliminary experiment to determine the appropriate dose of radiation for the subsequent experiments.

Cell proliferation analysis. Cell proliferation was determined by an MTT assay. Cells $\left(6 \times 10^{4} / \mathrm{ml}\right)$ in the logarithmic phase were sowed into the wells of 96 -well plates and incubated for $12 \mathrm{~h}$ at $37^{\circ} \mathrm{C}$ with $5 \% \mathrm{CO}_{2}$. Along with a control group, cells were treated with PBS, 6 Gy doses of radiation, and $100 \mathrm{nmol} / \mathrm{l}$ pcDNA3.1-RbAp48 and pcDNA3.1 vectors. The cells were subsequently maintained at $37^{\circ} \mathrm{C}$ with $5 \% \mathrm{CO}_{2}$ for
12, 24 and $48 \mathrm{~h}$. A volume of $50 \mu \mathrm{l}$ MTT solution was added into each well, and cells were transferred to the incubator for $4 \mathrm{~h}$. Subsequently, $100 \mu \mathrm{l}$ dimethyl sulfoxide was added into each well. The absorbance was read at wavelengths of 570 and $630 \mathrm{~nm}$ using a microplate reader (cat. no. SMR16.1; Uscn Life Sciences, Inc., Wuhan, China). Cell proliferation was determined in terms of the percentage of cell survival.

Flow cytometry (FCM). FCM was used for the analysis of the cell apoptosis and cell cycle. For cell apoptosis analysis, cells were harvested following transfection for $48 \mathrm{~h}$ and fixed in $70 \%$ ethanol at room temperature overnight. Cells prepared for assessment were first washed with PBS and subsequently resuspended in Annexin V-fluorescein iosthiocyanate and propidium iodide (PI; Shanghai Yeasen Biotechnology Co., Ltd., Shanghai, China) at $37^{\circ} \mathrm{C}$ for $30 \mathrm{~min}$. A flow cytometer (FACSCalibur; BD Biosciences, Franklin Lakes, NJ, USA) was used to assess cell apoptosis.

Cell cycle analysis. Following digestion with $0.25 \%$ trypsin, $\sim 5 \times 10^{7}$ cells were plated into 6 -well plates and incubated for $24 \mathrm{~h}$ at $37^{\circ} \mathrm{C}$ with $5 \% \mathrm{CO}_{2}$. Following treatment with radiation and mock or RbAp48 vector, the medium was removed and cells were washed with PBS three times. Cells were digested with $0.25 \%$ trypsin, placed in $15 \mathrm{ml}$ centrifuge tubes and centrifuged for $5 \mathrm{~min}$ at $1,000 \mathrm{x}$ g at $4^{\circ} \mathrm{C}$ and supernatant was subsequently discarded. Cells were resuspended following washing with PBS, and subsequently centrifuged for $5 \mathrm{~min}$ at $1,000 \mathrm{x}$ g at $4^{\circ} \mathrm{C}$, and the supernatant was discarded. Pre-cooled $70 \%$ ethanol $\left(4^{\circ} \mathrm{C} ; 1 \mathrm{ml}\right)$ was added into cells and the cells were gently blown with a pipette. Following this, cells were stored in a refrigerator at $4^{\circ} \mathrm{C}$ overnight. Cells were centrifuged for $5 \mathrm{~min}$ at $1,000 \mathrm{x} \mathrm{g}$ at $4^{\circ} \mathrm{C}$, ethanol was discarded and cells were washed with PBS three times. PBS (500 $\mu 1)$ containing PI $(50 \mu \mathrm{g} / \mathrm{ml})$, RNase A $(100 \mu \mathrm{g} / \mathrm{ml})$ and Triton X-100 $(0.2 \%)$ was added to the cells, which were incubated in the dark for $30 \mathrm{~min}$ at $4^{\circ} \mathrm{C}$. The results were detected by FCM and cell cycle analysis was performed with FlowJo 10 software (FlowJo LLC, Ashland, OR, USA).

Reverse transcription-quantitative polymerase chain reaction $(R T-q P C R)$ analysis. TRIzol ${ }^{\circledR}$ reagent (Tiangen Biotech Co., Ltd., Beijing, China) was used to extract total RNA from cells. According to the manufacturer's protocols, $2 \mu \mathrm{g}$ of RNA was used for cDNA synthesis using the First Strand cDNA Synthesis kit (Sigma-Aldrich; Merck KGaA, Darmstadt, Germany). RT-qPCR was performed using the SYBR Green Premix reagent (TakaraBio, Inc., Otsu, Japan) in an ABI 7500 Thermocycler (Thermo Fisher Scientific, Inc.). The PCR thermocycling conditions were as follows: Initial denaturation for $10 \mathrm{~min}$ at $95^{\circ} \mathrm{C}, 40$ cycles of $95^{\circ} \mathrm{C}$ for $5 \mathrm{sec}$ and $65^{\circ} \mathrm{C}$ for $31 \mathrm{sec}$, followed by $95^{\circ} \mathrm{C}$ for $15 \mathrm{sec}, 60^{\circ} \mathrm{C}$ for $1 \mathrm{~min}, 95^{\circ} \mathrm{C}$ for $15 \mathrm{sec}$ and a final extension at $72^{\circ} \mathrm{C}$ for $10 \mathrm{~min}$ and finally held at $4^{\circ} \mathrm{C}$. $\beta$-actin was used as the internal control for normalization. The primers used for RT-qPCR were listed in Table I.

Western blotting. Treated cells were lysed in radioimmunoprecipitation lysis and extraction buffer (Thermo Fisher Scientific, Inc.) on ice. Cells were broken into pieces with an 
Table I. Sequences of the primers used in reverse transcription-quantitative polymerase chain reaction.

\begin{tabular}{|c|c|c|c|}
\hline Name & NCBI gene ID & Direction & Sequence $\left(5^{\prime}-3^{\prime}\right)$ \\
\hline \multirow[t]{2}{*}{ RbAp48 } & 5928 & Forward & CCTCGACATGGCCTAACAGTG \\
\hline & & Reverse & TCCCCAGGACAAGTCGATGA \\
\hline \multirow[t]{2}{*}{ Cyclin B1 } & 891 & Forward & TCTGCTGGGTGTAGGTCCTT \\
\hline & & Reverse & ACCAATGTCCCCAAGAGCTG \\
\hline \multirow[t]{2}{*}{ P53 } & 8273 & Forward & CCCAGTAGGGACCCATTCATTG \\
\hline & & Reverse & CGGCTGGAGATATTGGGTGA \\
\hline \multirow[t]{2}{*}{$\mathrm{P} 21$} & 1026 & Forward & TGCCGAAGTCAGTTCCTTGT \\
\hline & & Reverse & CATTAGCGCATCACAGTCGC \\
\hline \multirow[t]{2}{*}{ Caspase-3 } & 836 & Forward & GCGGTTGTAGAAGTTAATAAAGGTA \\
\hline & & Reverse & CATGGCACAAAGCGACTGG \\
\hline \multirow[t]{2}{*}{ Caspase-7 } & 840 & Forward & CTCCAGGGACTATGCGTGC \\
\hline & & Reverse & GAATCCTCAACCCCСТGCTC \\
\hline \multirow[t]{2}{*}{ Caspase-9 } & 842 & Forward & CAGGCCCCATATGATCGAGG \\
\hline & & Reverse & TCGACAACTTTGCTGCTTGC \\
\hline \multirow[t]{2}{*}{ PARP } & 142 & Forward & TTCAACAAGCAGCAAGTGCC \\
\hline & & Reverse & CCTTTGGGGTTACCCACTC \\
\hline \multirow[t]{2}{*}{$\mathrm{Bcl}-2$} & 596 & Forward & GGGAGGATTGTGGCCTTCTT \\
\hline & & Reverse & ACTTGTGGCCCAGATAGGCA \\
\hline \multirow[t]{2}{*}{ Bax } & 581 & Forward & GTCTTTTTCCGAGTGGCAGC \\
\hline & & Reverse & GGAGACAGGGACATCAGTCG \\
\hline \multirow[t]{2}{*}{$\beta$-actin } & 60 & Forward & TTCTCAAGATCTGGACAGACG \\
\hline & & Reverse & TGGCAACTTCTTCCTGCAAC \\
\hline
\end{tabular}

RbAp48, retinoblastoma-binding protein 4; P53, cellular tumor antigen p53; P21, cyclin dependent kinase inhibitor 1A; PARP, poly(ADP-ribose) polymerase 1; Bcl-2, B-cell lymphoma 2; Bax, Bcl-2-associated X protein.

ultrasonic cell disruptor. Supernatant was collected following centrifugation at $1,000 \mathrm{xg}$ at $4^{\circ} \mathrm{C}$ for $10 \mathrm{~min}$. According to the manufacturer's protocols, protein concentration was determined using a bicinchoninic acid assay reagent (Bio-Rad Laboratories, Inc. Hercules, CA, USA). An equal quantity of proteins (50 $\mu \mathrm{g} /$ lane) was separated using 10\% SDS-PAGE. Proteins obtained were transferred to nitrocellulose membranes for $1.5 \mathrm{~h}$. Membranes were blocked in 5\% low-fat dried milk at room temperature for $2 \mathrm{~h}$. The following primary antibodies were incubated with membranes at $4^{\circ} \mathrm{C}$ overnight: Anti-RbAp48 (1:1,000; cat. no. ab1765; Abcam, Cambridge, MA, USA), anti-cyclin B1 (1:1,000; cat. no. ab72; Abcam), anti-cell division control protein 2 homolog (Cdc2; 1:2,000; cat. no. ab12568; Abcam), anti-phosphorylated (p)-Cdc2 (1:1,000; cat. no. ab258965; Abcam), anti-p-M-phase inducer phosphatase 3 (Cdc25c; 1:500; cat. no. ab62191), anti-Cdc25c (1:1,000, cat. no. ab32444; Abcam), anti-cleaved caspase-3 (1:1,000; cat. no. ab2302; Abcam), anti-cleaved caspase-7 (1:500; cat. no. ab32042; Abcam), anti-cleaved caspase-9 (1:1,000; cat. no. ab1324; Abcam), anti-cleaved poly (ADP-ribose) polymerase (PARP; 1:5,000; cat. no. ab32064; Abcam) anti-p-PI3K (1:1,000; cat. no. ab182651; Abcam), anti-PI3K (1:1,000; cat. no. ab151549; Abcam) anti-p-Akt (1:5,000; cat. no. ab81283; Abcam), anti-Akt (1:5,000; cat. no. ab182729; Abcam) and anti- $\beta$-actin (1:1,000; cat. no. ab8227; Abcam) at $4^{\circ} \mathrm{C}$. Rabbit anti-mouse immunoglobulin G (IgG; cat. no. 58802; 1:7,000;
CST Biological Reagents Co. Ltd., Shanghai, China), goat anti-mouse IgG (cat. no. ab7064; 1:8,000; Abcam) and mouse anti-goat IgG (cat. no. BA1074; 1:7,000; Invitrogen; Thermo Fisher Scientific, Inc.) horseradish peroxidase (HRP)-conjugated secondary antibodies were incubated with the membranes at room temperature for $2 \mathrm{~h}$. Bands were visualized using enhanced chemiluminescent reagent (EMD Millipore, Billerica, MA, USA). Images were captured using the Fujifilm LAS-3000 Imager imaging system (Fuji Photo Film Co., Ltd., Tokyo, Japan) and the software used was the LAS-3000 Image Reader (Fuji Photo Film Co., Ltd.).

Statistical analysis. Results are presented as the mean \pm standard error of mean using SPSS 20.0 (IBM Corp., Armonk, NY, USA). Data were analyzed by one-way analysis of variance, followed by Tukey's post-hoc test. Each experiment was repeated three times. $\mathrm{P}<0.05$ was considered to indicate a statistically significant difference.

\section{Results}

Radiation enhances the expression level of RbAp48 in AGS cells. RT-qPCR and western blot analysis was performed to evaluate the expression levels of RbAp48 in AGS cells under various experimental conditions. AGS cells were treated with increasing intensities of radiation (2, 4 and 6 Gy). The results 
A

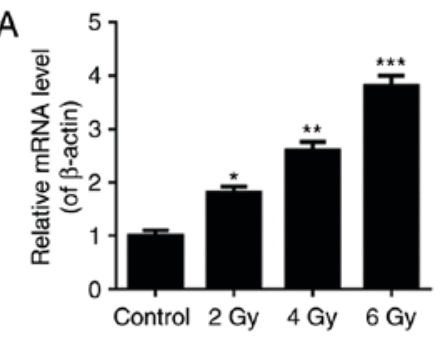

C
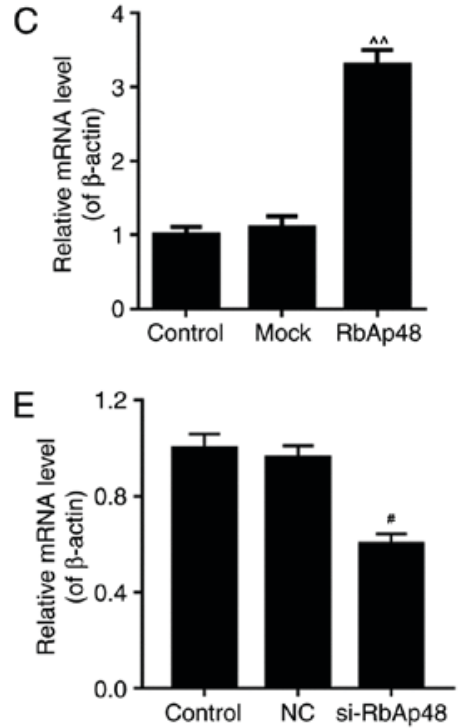

B
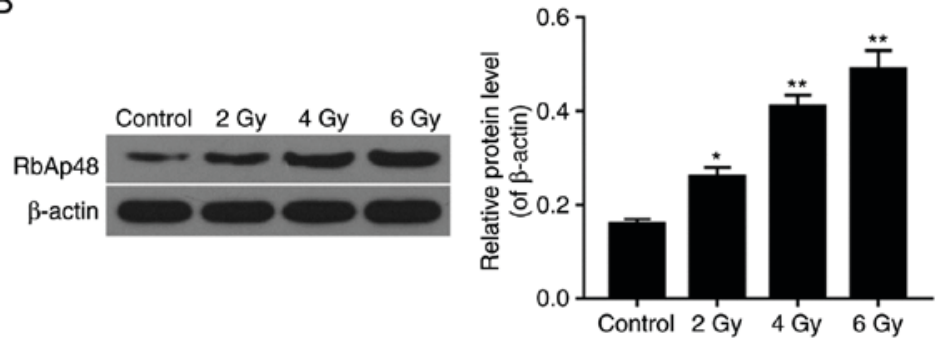

D
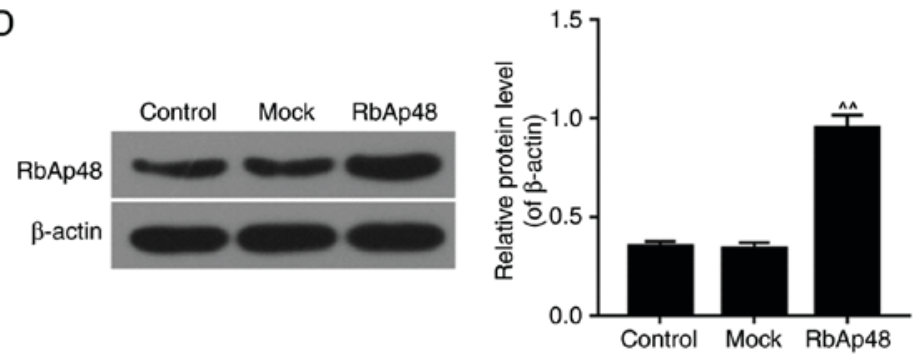

F
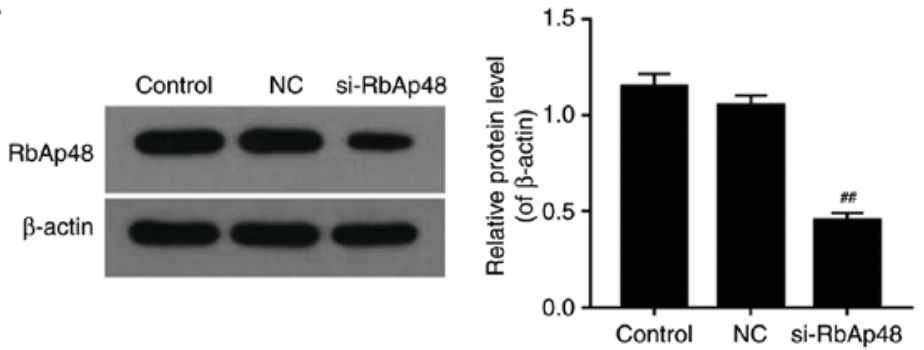

Figure 1. Radiation enhances the expression levels of RbAp48 in AGS cells. Reverse transcription-quantitative polymerase chain reaction and western blot analysis were performed to detect the (A) mRNA and (B) protein expression levels of RbAp48 in AGS cells treated with increasing radiation intensities (C) mRNA and (D) protein expression of RbAp48 was determined in AGS cells transfected with RbAp48 overexpression vector. (E) mRNA and (F) protein expression of RbAp48 was also determined in AGS cells transfected with RbAp48 siRNA and unspecific scrambled siRNA. ${ }^{*} \mathrm{P}<0.05$, ${ }^{* *} \mathrm{P}<0.01,{ }^{* * *} \mathrm{P}<0.001$ vs. control; ${ }^{\wedge} \mathrm{P}<0.01$ vs. mock; ${ }^{\#} \mathrm{P}<0.05,{ }^{\# \#} \mathrm{P}<0.01$ vs. NC. RbAp48, retinoblastoma-binding protein 4; control, PBS; siRNA, small interfering RNA; si-RbAp48, RbAp48 siRNA; mock, pcDNA3.1; NC, unspecific scrambled siRNA negative control.

revealed that the mRNA (Fig. 1A) and protein (Fig. 1B) expression of RbAp48 was significantly higher in cells exposed to radiation compared with the control group, in a dose-dependent manner $(\mathrm{P}<0.05)$. Additionally, following AGS cell transfection with pcDNA3.1-RbAp48 plasmids, the mRNA (Fig. 1C) and protein (Fig. 1D) expression levels of RbAp48 were significantly higher than control and mock groups $(\mathrm{P}<0.05)$. Furthermore, the mRNA (Fig. 1E) and protein (Fig. 1F) levels of RbAp48 in the si-RbAp48 transfected group were significantly lower, compared with the control and NC groups $(\mathrm{P}<0.05)$. These data demonstrated that radiation increased RbAp48 expression and that the transfection efficiency of RbAp48 was high in AGS cells.

RbAp48 combined with radiation reduces the cell proliferation of AGS cells. To investigate the effects of radiation and RbAp48 expression on AGS cell proliferation, an MTT assay was performed. As presented in Fig. 2A, a significant decrease in cell proliferation was observed in the control+RAD and mock+RAD groups. The cell proliferation of AGS cells was further decreased in the groups transfected with RbAp48 at 12,24 and $48 \mathrm{~h}(\mathrm{P}<0.05)$. These data indicated that radiation exposure may have reduced the proliferation of AGS cells, and this reduction was stronger when combined with RbAp48 overexpression.
RbAp48 overexpression combined with radiation exposure causes $G_{2}$ cell cycle arrest. In order to identify the mechanism of AGS cell growth inhibition with combination of RbAp48 and radiation exposure, cell cycle analysis was performed. As presented in Fig. 2B and C, the percentage of cells in the $\mathrm{G}_{2}$ phase was markedly higher in the RbAp48+RAD group (48.98\%), compared with the other groups (control, 10.47\%; Mock, 9.29\%; control+RAD, 22.85\%; mock+RAD, 23.36\%). This phenomenon indicated that overexpression of RbAp48 in combination with radiation exposure arrested cells in the $\mathrm{G}_{2}$ phase.

Furthermore, the expression levels of cell cycle associated factors were evaluated in each group by RT-qPCR and western blot analysis. It was demonstrated that radiation significantly reduced the mRNA expression of cyclin B1, and enhanced the expression of P53 and cyclin dependent kinase inhibitor (P21; Fig. 3A; $\mathrm{P}<0.05)$. When cells were exposed to a combination of radiation and $\mathrm{RbAp} 48$ overexpression, the downregulation of cyclin B1 expression and upregulation of P53 and P21 expression was more significant $(\mathrm{P}<0.01)$. As presented in Fig. $3 \mathrm{~B}$, western blot analysis demonstrated that compared with the other groups, RbAp48 overexpression combined with radiation significantly decreased the protein expression of cyclin B1 $(\mathrm{P}<0.001)$. Furthermore, in the RbAp48+RAD group, the protein expression of $\mathrm{p}-\mathrm{Cdc} 2$ (Tyr15) in AGS cells was significantly increased (Fig. 3C), and p-Cdc25c expression 
A

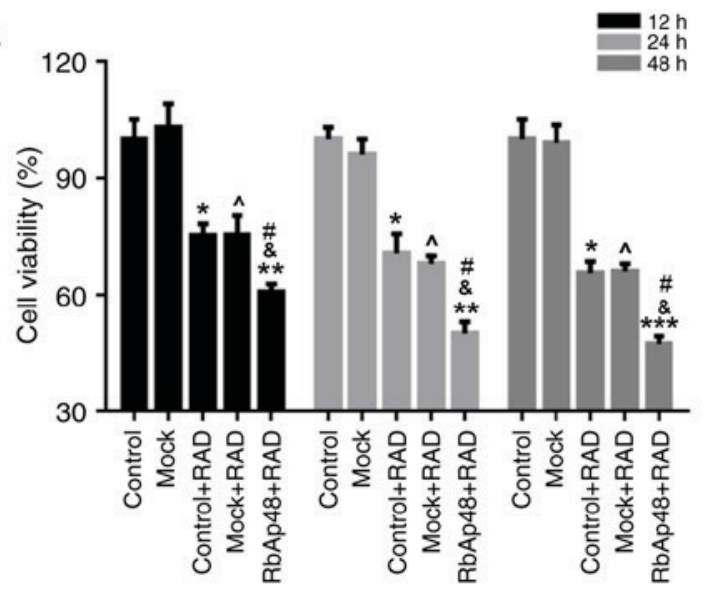

B

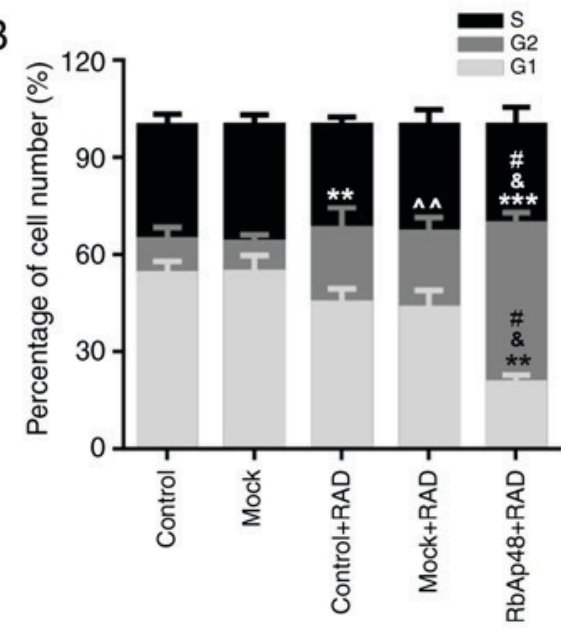

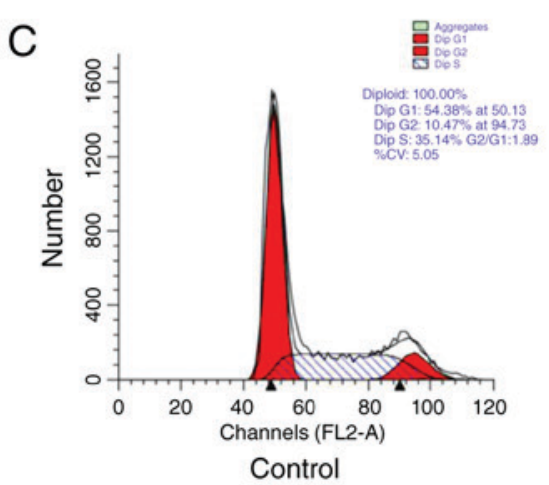
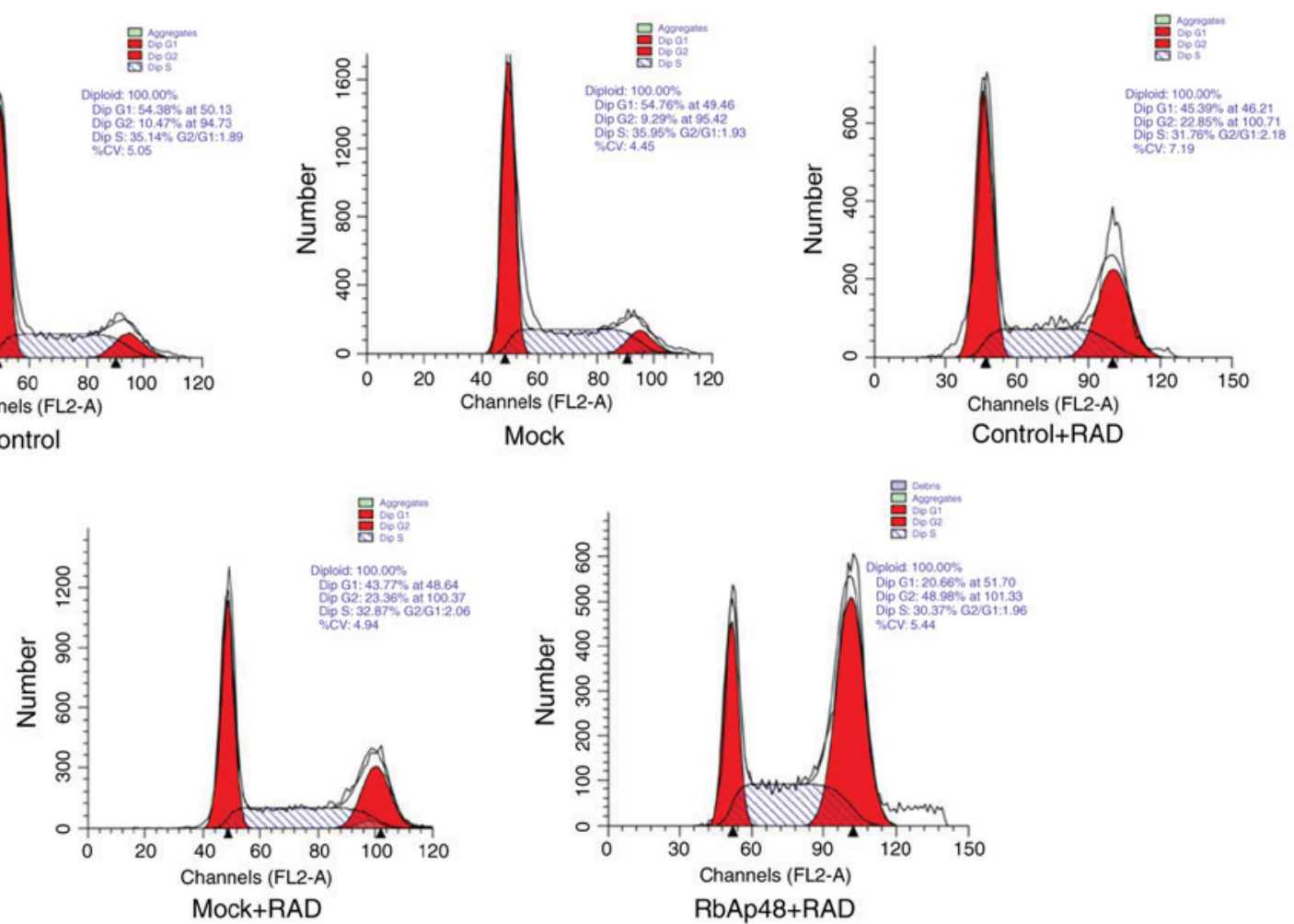

Figure 2. RbAp48 in combination with radiation inhibits cell proliferation and results in G2 cell cycle arrest. (A) An MTT assay was performed to assess AGS cell proliferation. (B) The percentage of cells in each phase was determined by (C) flow cytometry analysis. ${ }^{*} \mathrm{P}<0.05,{ }^{* * *} \mathrm{P}<0.01,{ }^{* * *} \mathrm{P}<0.001 \mathrm{vs}$. control; ${ }^{\wedge} \mathrm{P}<0.05,{ }^{\wedge} \mathrm{P}<0.01$, vs. mock; ${ }^{\&} \mathrm{P}<0.05$ vs. control+RAD; ${ }^{~} \mathrm{P}<0.05$ vs. mock+RAD. RbAp48, retinoblastoma-binding protein 4; control, PBS; mock, pcDNA3.1; RAD, 6 Gy radiation.

was significantly reduced (Fig. 3D; $\mathrm{P}<0.01$ ). Based on the aforementioned results, it was concluded that RbAp48 overexpression combined with radiation exposure resulted in $\mathrm{G}_{2}$ cell cycle arrest, through regulation of associated cell cycle factor expression levels.

RbAp48 combined with radiation induces AGS cell apoptosis. In order to determine the effect ofRbAp48 and radiation on cell apoptosis, FCM analysis was performed in the present study. It was demonstrated that the percentage of apoptotic cells was significantly increased in the control+RAD and mock+RAD groups compared with the control $(\mathrm{P}<0.01)$, indicating that radiation induced AGS cell apoptosis. Additionally, the percentage of apoptosis in the RbAp48+RAD group was significantly higher than the other groups (Fig. 4). These data suggested that RbAp48 in combination with radiation further induced AGS cell apoptosis.

The expression levels of associated apoptosis proteins were presented in Fig. 5. With regards to the RT-qPCR data (Fig. 5A), the expression levels of caspase-3, caspase-7, caspase-9, PARP and Bax were significantly higher $(\mathrm{P}<0.01)$, while the expression level of Bcl-2 was significantly lower $(\mathrm{P}<0.05)$ in the RAD groups compared with the control. In addition, expression levels of caspase-3, caspase-7, caspase-9, PARP and Bax were further increased and Bcl-2 expression was further decreased in the RbAp48+RAD group, compared with the control+RAD and mock+RAD groups. Furthermore, the western blotting data of caspase-3, cleaved caspase-7, 
A

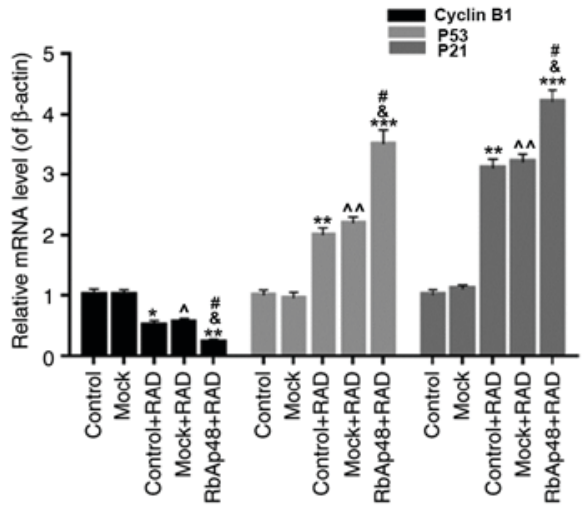

B

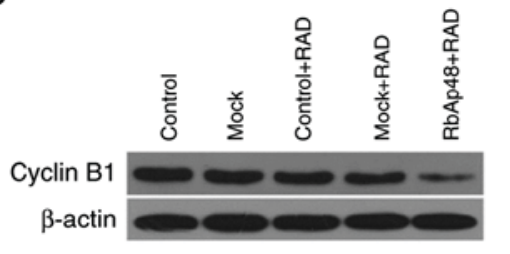

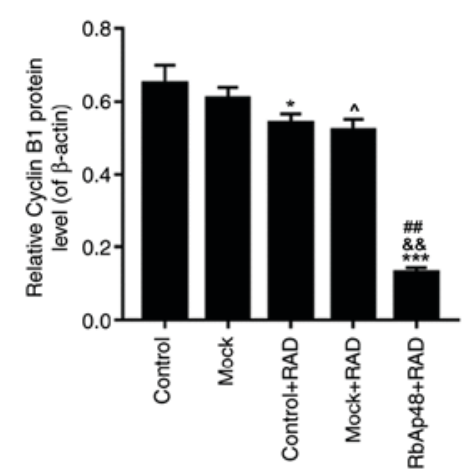

C
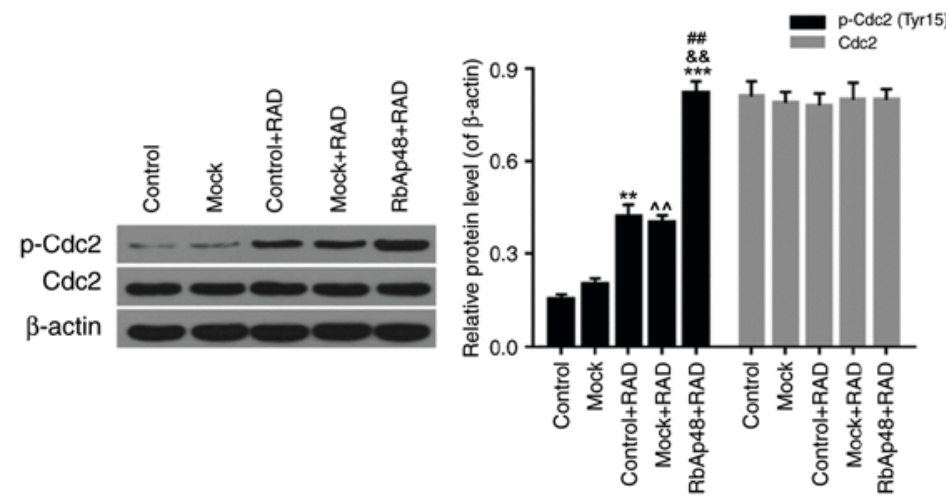

D

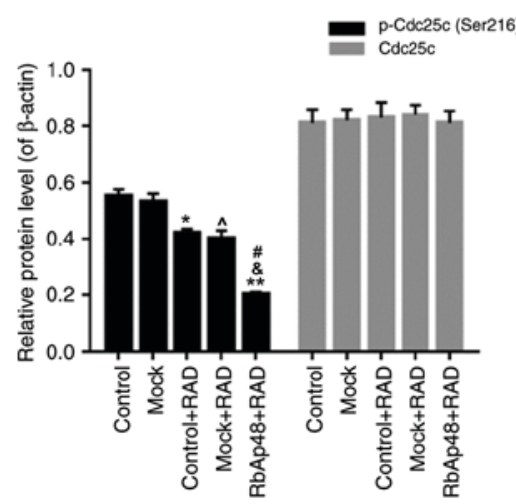

Figure 3. RbAp48 in combination with radiation regulates the expression of cyclin B1, P53, P21, Cdc2 and Cdc25c in AGS cells. (A) Reverse transcription-quantitative polymerase chain reaction was performed to determine the expression levels of cyclin B1, P53 and P21 in AGS cells. Western blot analysis was performed to evaluate the expression levels of (B) cyclin $\mathrm{B} 1,(\mathrm{C}) \mathrm{p}-\mathrm{Cdc} 2 / \mathrm{Cdc} 2$ and (D) $\mathrm{p}-\mathrm{Cdc} 25 \mathrm{c} / \mathrm{Cdc} 25 \mathrm{c}$. ${ }^{*} \mathrm{P}<0.05$, ${ }^{* *} \mathrm{P}<0.01$, ${ }^{* * *} \mathrm{P}<0.001$ vs. control; ${ }^{\wedge} \mathrm{P}<0.05,{ }^{\wedge} \mathrm{P}<0.01$ vs. mock; ${ }^{\circledR} \mathrm{P}<0.05$, ${ }^{\&} \mathrm{P}<0.01$ vs. control+RAD; ${ }^{\#} \mathrm{P}<0.05,{ }^{\# \#} \mathrm{P}<0.01$ vs. mock $+\mathrm{RAD}$. RbAp48, retinoblastoma-binding protein 4; control, $\mathrm{PBS}$; mock, pcDNA3.1; RAD, 6 Gy radiation; P53, cellular tumor antigen p53; P21, cyclin dependent kinase inhibitor 1A; p-, phosphorylated; Cdc2, cell division control protein 2 homolog; Cdc25c, M-phase inducer phosphatase 3.

cleaved caspase-9, and cleaved PARP expression displayed a similar trend (Fig. 5B). Therefore, it was demonstrated that RbAp48 combined with radiation induced AGS cell apoptosis through regulation of associated apoptosis marker expression.

RbAp48 combined with radiation inhibits the PI3K/Akt pathway. Western blotting was also performed to explore the functional mechanism of RbAp48 in combination with radiation in AGS cell growth inhibition. The expression levels of p-PI3K, PI3K, p-Akt, and Akt were detected. In the RAD groups, the protein expression levels of p-PI3K were significantly lower than the control and mock groups. However, the expression levels of total PI3K were not significantly different among the five groups (Fig. 6A). Additionally, compared with the control and mock groups, protein expression levels of p-Akt were markedly reduced by radiation, while the expression levels of total Akt were not significantly different among the five groups (Fig. 6B). Furthermore, overexpression of $\mathrm{RbAp} 48$ resulted in further reductions in $\mathrm{p}$-PI3K and $\mathrm{p}-\mathrm{Akt}$ expression, compared with the radiation only groups $(\mathrm{P}<0.01)$. Therefore, it was confirmed that RbAp48 combined with radiation affected the PI3K/Akt pathway activity, which may have been involved in AGS cell growth inhibition and induction of AGS cell apoptosis.

si-RbAp48 represses cell apoptosis and RbAp48 in combination with radiation promotes cell apoptosis via PI3K/Akt pathway inhibition. FCM analysis was performed in order to 
A
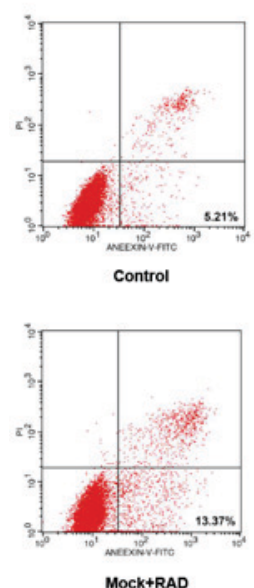

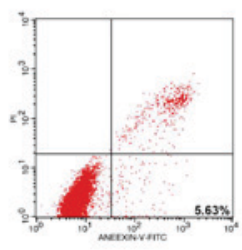

Mock

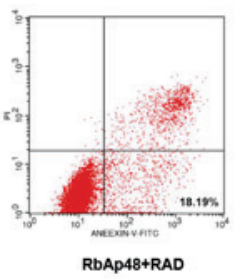

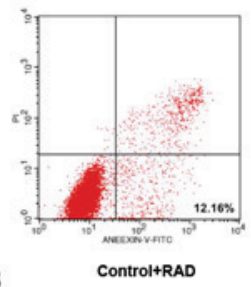

B

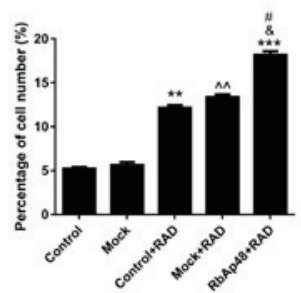

Figure 4. RbAp48 in combination with radiation induces AGS cell apoptosis. (A) Flow cytometry analysis was performed and (B) the percentage of apoptotic cells was calculated. ${ }^{* *} \mathrm{P}<0.01,{ }^{* * * *} \mathrm{P}<0.001$ vs. control; ${ }^{\wedge} \mathrm{P}<0.01$ vs. mock; ${ }^{\circledR} \mathrm{P}<0.05$ vs. control+RAD; ${ }^{*} \mathrm{P}<0.05$ vs. mock+RAD. RbAp48, retinoblastoma-binding protein 4; control, PBS; mock, pcDNA3.1; RAD, 6 Gy radiation; FITC, fluorescein isothiocyanate; PI, propidium iodide.

\section{A}
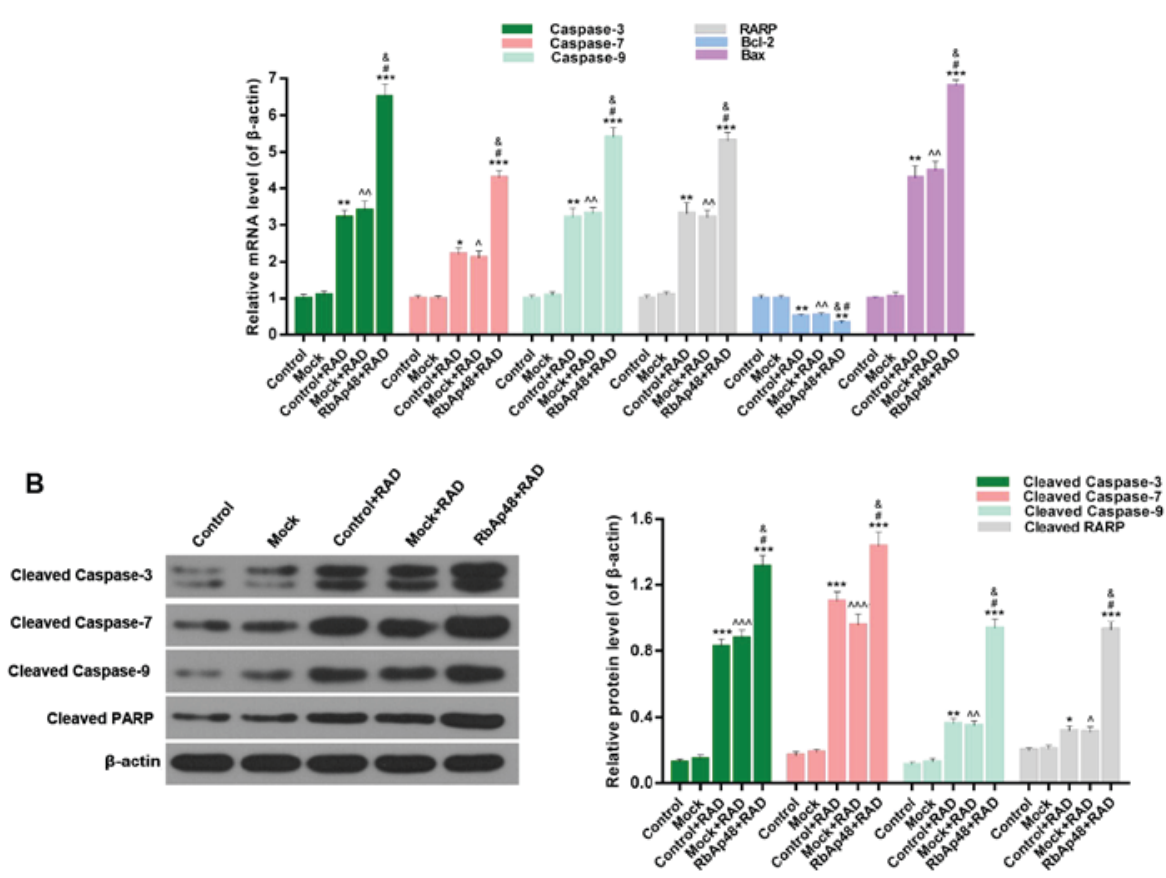

Figure 5. RbAp48 in combination with radiation regulates the expression of apoptosis-associated proteins. (A) Reverse transcription-quantitative polymerase chain reaction was performed to assess the expression levels of caspase-3, -7, -9, PARP, Bcl-2 and Bax in AGS cells. (B) Western blot analysis was performed to evaluate the expression levels of cleaved caspase- $3,-7,-9$ and cleaved PARP. ${ }^{\prime \prime} \mathrm{P}<0.05,{ }^{* * *} \mathrm{P}<0.01,{ }^{* * * *} \mathrm{P}<0.001$ vs. control; ${ }^{\wedge} \mathrm{P}<0.05,{ }^{\wedge} \mathrm{P}<0.01,{ }^{\wedge \wedge} \mathrm{P}<0.001$ vs. mock; ${ }^{\&} \mathrm{P}<0.05$ vs. control+RAD; ${ }^{\#} \mathrm{P}<0.05$ vs. mock+RAD. RbAp48, retinoblastoma-binding protein 4; control, PBS; mock, pcDNA3.1; RAD, 6 Gy radiation; PARP, poly(ADP-ribose) polymerase 1; Bcl-2, B-cell lymphoma 2; Bax, Bcl-2-associated X protein.

analyze the effect of si-RbAp48 on cell apoptosis, and to determine if the combination of RbAp48 and radiation induced apoptosis via PI3K/Akt pathway analysis. The results revealed that compared with the mock group, the apoptotic cell number in the si-RbAp48 group was reduced, and was significantly increased in the RbAp48 overexpression group. In addition, cells treated with a combination of RbAp48 and radiation had the highest proportion of apoptotic cells. Furthermore, compared with the RbAp48+RAD group, the number of apoptotic cells in the RbAp48+RAD+IGF-1 group was significantly lower $(\mathrm{P}<0.05$; Fig. 7). Therefore, it was demonstrated that si-RbAp48 repressed cell apoptosis, and RbAp48 in combination with radiation promoted cell apoptosis via PI3K/Akt pathway inhibition.

\section{Discussion}

$\mathrm{RbAp} 48$, as a binding protein of tumor suppressor protein $\mathrm{Rb}$, is involved in various biological functions, including chromatin assembly, histone modification and nucleosome 
A

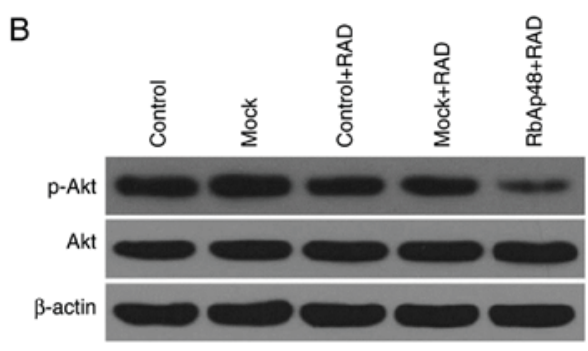

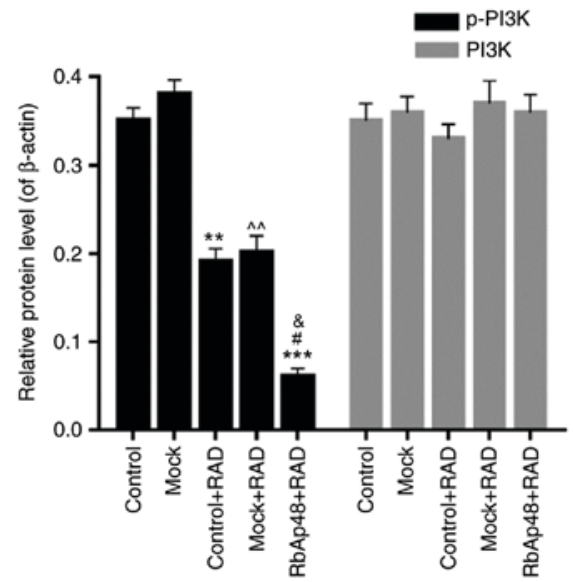

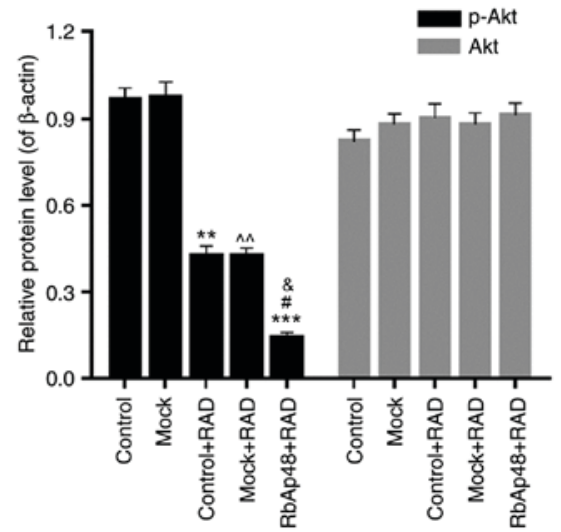

Figure 6. RbAp48 in combination with radiation inhibits the PI3K/Akt pathway. Western blot analysis was performed to assess the expression levels of (A) p-PI3K, PI3K, (B) p-Akt and Akt in AGS cells. ${ }^{* *} \mathrm{P}<0.01,{ }^{* * *} \mathrm{P}<0.001$ vs. control; ${ }^{\wedge} \mathrm{P}<0.01$ vs. mock; ${ }^{\&} \mathrm{P}<0.05$ vs. control+RAD; ${ }^{\sharp} \mathrm{P}<0.05$ vs. mock+RAD. RbAp48, retinoblastoma-binding protein 4; control, PBS; mock, pcDNA3.1; RAD, 6 Gy radiation; p-, phosphorylated; PI3K, phosphoinositide 3-kinase; Akt, protein kinase B.

remodeling $(21,22)$. Studies have demonstrated that the $\mathrm{Rb} / \mathrm{RbAp} 48$-associatedhistone acetyl transferase complex participates in the inhibition of E2F regulatory gene transcription (23-27). It has been reported that RbAp48 promotes radiosensitivity in breast, melanoma and cervical cancer cells $(28,29)$. However, the effects of RbAp48 in gastric cancer remain unclear.

AGS gastric cancer cells were used in the present study. Radiation treatment was administered and the mRNA and protein expression of RbAp48 had significantly increased in the AGS cells, suggesting that RbAp48 is a radiation-inducible protein in gastric cancer. This finding provided the basis for further investigation. Furthermore, compared with the cells treated with radiation only, cell proliferation was significantly inhibited in cells overexpressing RbAp48 in addition to radiation exposure. The mechanism underlying this phenomenon may be associated with the inhibition of oncogene expression and increased cancer suppressor gene expression (30). In the present study, gastric cancer cell proliferation was significantly inhibited following treatment with RbAp48 in combination with radiation. However, the mechanism underlying the inhibition of AGS cell proliferation by this combination may be complex. The present preliminary study suggested that RbAp48 arrested the AGS cells at the $G_{2}$ phase and induced apoptosis. These processes may serve a critical role in $\mathrm{RbAp} 48$-induced radiosensitivity.
Radiation-induced cell responses include cell cycle arrest, apoptosis and DNA repair, as a complex result of multiple gene involvement (31). In response to radiation-induced DNA impairment, DNA repair, $\mathrm{G}_{2}$ phase arrest and apoptosis predominantly occur $(32,33)$. In the present study, it was demonstrated that the $G_{2}$ phase arrest was increased by radiation, and this effect was further increased by RbAp48 overexpression. Typically, the $\mathrm{G}_{1}$ and $\mathrm{G}_{2}$ phases are more sensitive to radiation, whereas the $S$ phase is the least sensitive. Thus, the $\mathrm{G}_{2}$ phase is considered a key point in cancer radiotherapy (31). Previous research has reported that RbAp48 may enhance the proportion of HS-578T cells in the $G_{2}$ phase (28), which was in accordance with the results of the present study.

Radiation leads to apoptosis in cancer cells, indicating that apoptosis is a key mechanism in tumor cell radiotherapy. The detection and signaling system of DNA impairment controls cell cycle checkpoints and results in subsequent cell death. The present study revealed that overexpression of RbAp48 significantly increased the apoptotic rate in combination with radiotherapy. Additionally, RbAp48 silencing markedly attenuated apoptosis in radiotherapy-treated AGS cells. These results demonstrated that $\mathrm{RbAp} 48$ is a radiotherapy-induced protein in gastric cancer cells, which promoted the radiosensitivity of gastric cancer cells through increased cell apoptosis.

Cell cycle arrest, DNA repair and apoptosis initially occur in response to DNA impairment. Cyclin B1, Cdc2 and Cdc25c 

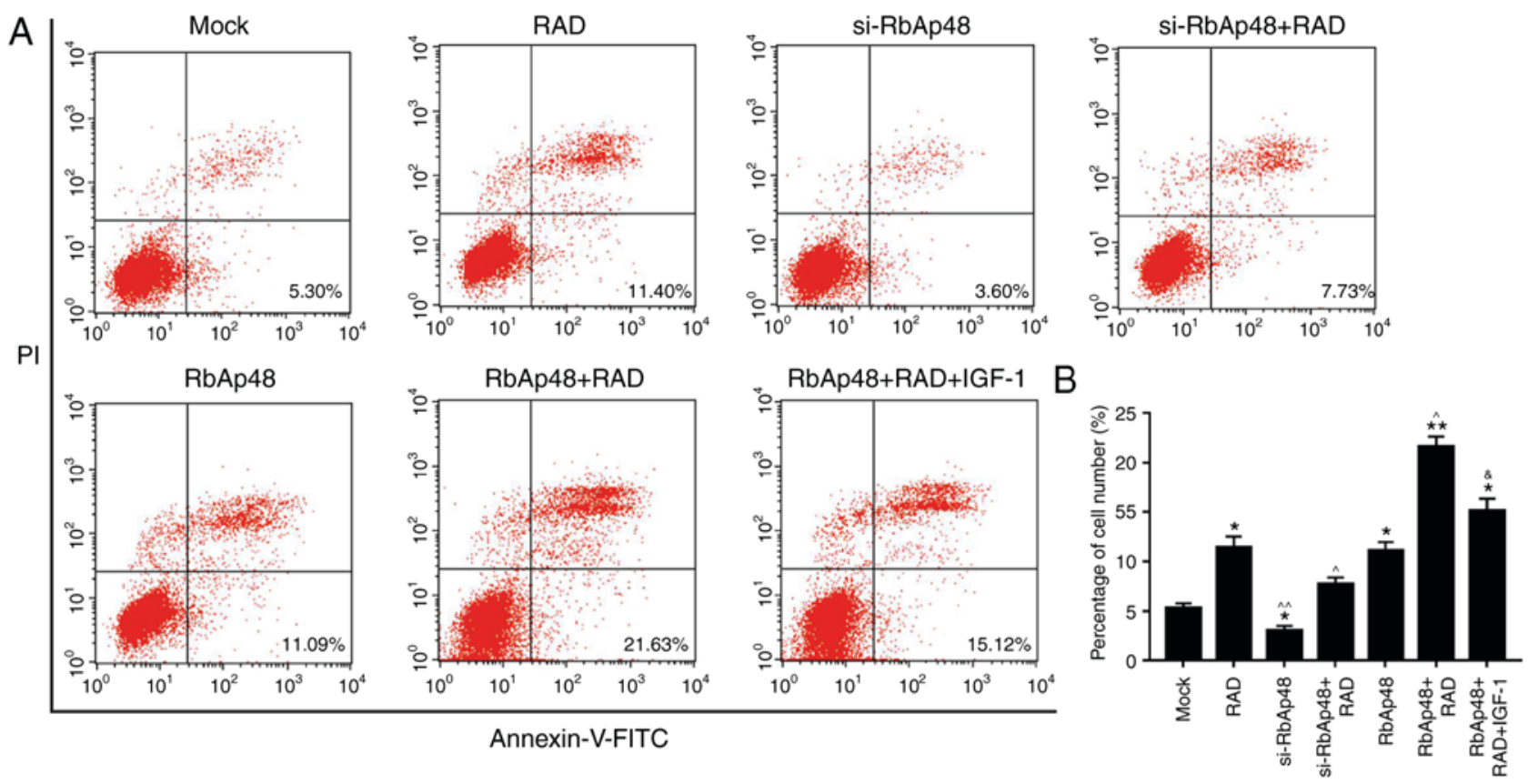

Figure 7. si-RbAp48 represses cell apoptosis, and RbAp48 in combination with radiation promotes cell apoptosis via PI3K/Akt pathway inhibition. (A) Flow cytometry analysis was performed and (B) the percentage of apoptotic cells was calculated. IGF-1 was used as a PI3K/Akt pathway agonist. "P<0.05, ${ }^{* *} \mathrm{P}<0.01$ vs. mock; ${ }^{\wedge} \mathrm{P}<0.05,{ }^{\wedge} \mathrm{P}<0.01$ vs. $\mathrm{RAD} ;{ }^{\circledR} \mathrm{P}<0.05$ vs. RbAp48+RAD. RbAp48, retinoblastoma-binding protein 4; si-RbAp48, RbAp48 small interfering RNA; mock, pcDNA3.1; RAD, 6 Gy radiation; IGF-1, insulin-like growth factor 1; PI3K, phosphoinositide 3-kinase; Akt, protein kinase B; FITC, fluorescein isothiocyanate; PI, propidium iodide.

are critical to the radiographic response and mediate the cell cycle when DNA is impaired (34-38). The P53 gene is a tumor suppressor gene (39), and the P21 gene is an important member of the cyclin dependent kinase inhibitor family (40). P53 and P21 coordinate the association between cell cycle, DNA replication and repair, and thus closely associate tumor inhibition with cell cycle control (39-42). The present results demonstrated that overexpression of RbAp48 in combination with radiation significantly reduced the expression of cyclin $\mathrm{B} 1$ and $\mathrm{p}-\mathrm{Cdc} 25 \mathrm{c}$, and enhanced the expression of p-Cdc2, P53 and $\mathrm{P} 21$.

Caspases are key elements in the apoptotic pathway and participate in apoptosis signal transduction and execution. Research has indicated that caspase-3, -7 and -9 are involved in radiation-induced cell apoptosis $(43,44)$. In the present study, overexpression of RbAp48 in combination with radiotherapy markedly enhanced AGS cell apoptosis. Furthermore, RT-qPCR and western blotting data indicated that overexpression of RbAp48 in combination with radiation enhanced the expression levels of cleaved caspase-3, -7, -9 and cleaved PARP.

Furthermore, the functional mechanism underlying RbAp48 in combination with radiation in increasing AGS cell apoptosis was explored. PI3K is a class of kinases that generates second messenger molecules via activation of its substrates PIP2 and PIP3 (45). As a downstream effector of PI3K, Akt is a critical tumor factor (46). Activated Akt may regulate specific families of proteins (including the Bcl-2 family, caspase family and IKK family) associated with apoptosis and participate in the regulation of biological behavior of tumor cells (47-49). Previous studies have demonstrated that apoptosis is induced in gastric cancer cells via the PI3K/Akt pathway $(50,51)$. Therefore, it was hypothesized that AGS cell apoptosis, induced by RbAp48 overexpression in combination with radiation, was associated with PI3K/Akt pathway regulation. In the present study, the results of the RT-qPCR and western blot analysis demonstrated that overexpression of $\mathrm{RbAp} 48$ in combination with radiation significantly downregulated the expression levels of p-PI3K and p-Akt. In addition, the percentage of apoptotic cells in the RbAp48+RAD+IGF-1 group was significantly lower than that of the RbAp48+RAD group. Therefore, it was confirmed that overexpression of RbAp48 in combination with radiation increased apoptosis via inhibition of PI3K/Akt pathway activity.

Radiotherapy is one of the major treatment options for malignant tumors. Though tumor cells cannot be completely removed by surgery, surgery in combination with radiotherapy increases the possibility of patient survival $(52,53)$. However, certain tumor cells (glioma and pancreatic tumor) are not sensitive to radiation, which consequently results in treatment failure $(54,55)$. Therefore, improving radiosensitivity is key to improving the clinical outcomes of radiotherapy. Current clinical radiotherapy sensitization drugs, including cisplatin, 5-fluorouracil and gemcitabin, are effective; however, these drugs may additionally result in damaging effects in normal tissues $(56,57)$. Therefore, developing specific radiation-sensitive agents for tumors should be the direction of future radiotherapy research.

In conclusion, overexpression of RbAp48 in combination with radiation arrested AGS cells in $\mathrm{G}_{2}$ phase and induced apoptosis via regulation of the PI3K/Akt pathway. The present study established an experimental basis for clinical radiotherapy in combination with gene therapy to enhance radiosensitivity in gastric cancer. The results suggest that 
RbAp48 may be a potential genetic therapeutic target in gastric cancer. However, the specific effects of RbAp48 overexpression in healthy tissues remain unknown and require further investigation.

\section{Acknowledgements}

Not applicable.

\section{Funding}

No funding was received.

\section{Availability of data and materials}

All data generated and analyzed during this study are included in this published article.

\section{Authors' contributions}

XJ, RJ, YX, BY and YY made substantial contributions to the conception and designed the experimental scheme. ZF, ZW, LY and SW analyzed and interpreted data. XJ was a principal contributor in writing the manuscript. All authors read and approved the final manuscript.

\section{Ethics approval and consent to participate}

Not applicable.

\section{Patient consent for publication}

Not applicable.

\section{Competing interests}

The authors declared that they had no competing interests.

\section{References}

1. Danaei G, Vander Hoorn S, Lopez AD, Murray CJ and Ezzati M Comparative Risk Assessment collaborating group (Cancers) Causes of cancer in the world: Comparative risk assessment of nine behavioural and environmental risk factors. Lancet 366: 1784-1793, 2005.

2. Jemal A, Bray F, Center MM, Ferlay J, Ward E and Forman D: Global cancer statistics. CA Cancer J Clin 61: 69-90, 2011.

3. Guggenheim DE and Shah MA: Gastric cancer epidemiology and risk factors. J Surg Oncol 107: 230-236, 2013.

4. Jiang X, Tseng CC, Bernstein L and Wu AH: Family history of cancer and gastroesophageal disorders and risk of esophageal and gastric adenocarcinomas: A case-control study. BMC Cancer 14: 60, 2014.

5. Yaghoobi M, Bijarchi R and Narod SA: Family history and the risk of gastric cancer. Br J Cancer 102: 237-242, 2010.

6. Jemal A, Center MM, DeSantis C and Ward EM: Global patterns of cancer incidence and mortality rates and trends. Cancer Epidemiol Biomarkers Prev 19: 1893-1907, 2010.

7. Catalano V, Labianca R, Beretta GD, Gatta G, de Braud F and Van Cutsem E: Gastric cancer. Crit Rev Oncol Hematol 71: 127-164, 2009.

8. Wright JD and Herzog TJ: Human papillomavirus: Emerging trends in detection and management. Curr Womens Health Rep 2: 259-265, 2002.

9. Franco EL: Epidemiology of anogenital warts and cancer. Obstet Gynecol Clin North Am 23: 597-623, 1996.
10. Chun-Zhi Z, Lei H, An-Ling Z, Yan-Chao F, Xiao Y, Guang-Xiu W,Zhi-Fan J, Pei-Yu P, Qing-Yu Z and Chun-Sheng K: MicroRNA-221 and microRNA-222 regulate gastric carcinoma cell proliferation and radioresistance by targeting PTEN. BMC Cancer 10: 367, 2010.

11. Hamada M, Fujiwara T, Hizuta A, Gochi A, Naomoto Y, Takakura N, Takahashi K, Roth JA, Tanaka N and Orita K: The p53 gene is a potent determinant of chemosensitivity and radiosensitivity in gastric and colorectal cancers. J Cancer Res Clin Oncol 122: 360-365, 1996.

12. Qiu H, Yashiro M, Shinto O, Matsuzaki T and Hirakawa K: DNA methyltransferase inhibitor 5-aza-CdR enhances the radiosensitivity of gastric cancer cells. Cancer Sci 100: 181-188, 2009.

13. Furuyama T, Tie F and Harte PJ: Polycomb group proteins ESC and $\mathrm{E}(\mathrm{Z})$ are present in multiple distinct complexes that undergo dynamic changes during development. Genesis 35: 114-124, 2003.

14. Müller J, Hart CM, Francis NJ, Vargas ML, Sengupta A, Wild B, Miller EL, O'Connor MB, Kingston RE and Simon JA: Histone methyltransferase activity of a Drosophila Polycomb group repressor complex. Cell 111: 197-208, 2002.

15. Döhner H, Fischer K, Bentz M, Hansen K, Benner A, Cabot G, Diehl D, Schlenk R, Coy J, Stilgenbauer S, et al: p53 gene deletion predicts for poor survival and non-response to therapy with purine analogs in chronic B-cell leukemias. Blood 85: 1580-1589, 1995.

16. Eastham JA, Hall SJ, Sehgal I, Wang J, Timme TL, Yang G, Connell-Crowley L, Elledge SJ, Zhang WW, Harper JW, et al: In vivo gene therapy with $\mathrm{p} 53$ or $\mathrm{p} 21$ adenovirus for prostate cancer. Cancer Res 55: 5151-5155, 1995.

17. Lang FF, Bruner JM, Fuller GN, Aldape K, Prados MD, Chang S, Berger MS, McDermott MW, Kunwar SM, Junck LR, et al: Phase I trial of adenovirus-mediated p53 gene therapy for recurrent glioma: Biological and clinical results. J Clin Oncol 21: 2508-2518, 2003

18. Parthun MR, Widom J and Gottschling DE: The major cytoplasmic histone acetyltransferase in yeast: Links to chromatin replication and histone metabolism. Cell 87: 85-94, 1996.

19. Loyola A and Almouzni G: Histone chaperones, a supporting role in the limelight. Biochim Biophys Acta 1677: 3-11, 2004.

20. Scuto A, Zhang H, Zhao H, Rivera M, Yeatman TJ, Jove R and Torres-Roca JF: RbAp48 regulates cytoskeletal organization and morphology by increasing K-Ras activity and signaling through mitogen-activated protein kinase. Cancer Res 67: 10317-10324, 2007.

21. Brehm A, Miska EA, McCance DJ, Reid JL, Bannister AJ and Kouzarides T: Retinoblastoma protein recruits histone deacetylase to repress transcription. Nature 391: 597-601, 1998.

22. Luo RX, Postigo AA and Dean DC: Rb interacts with histone deacetylase to repress transcription. Cell 92: 463-473, 1998.

23. Bae SM, Lee CH, Cho YL, Nam KH, Kim YW, Kim CK, Han BD, Lee YJ, Chun HJ and Ahn WS: Two-dimensional gel analysis of protein expression profile in squamous cervical cancer patients. Gynecol Oncol 99: 26-35, 2005.

24. Cheng Q, Lau WM, Tay SK, Chew SH, Ho TH and Hui KM: Identification and characterization of genes involved in the carcinogenesis of human squamous cell cervical carcinoma. Int J Cancer 98: 419-426, 2002.

25. Pardo M, García A, Thomas B, Piñeiro A, Akoulitchev A Dwek RA and Zitzmann N: Proteome analysis of a human uveal melanoma primary cell culture by $2-\mathrm{DE}$ and MS. Proteomics 5: 4980-4993, 2005.

26. Verreault A, Kaufman PD, Kobayashi R and Stillman B: Nucleosome assembly by a complex of CAF-1 and acetylated histones H3/H4. Cell 87: 95-104, 1996.

27. Xue Y, Wong J, Moreno GT, Young MK, Côté J and Wang W: NURD, a novel complex with both ATP-dependent chromatin-remodeling and histone deacetylase activities. Mol Cell 2: 851-861, 1998.

28. Torres-Roca JF, Eschrich S, Zhao H, Bloom G, Sung J, McCarthy S, Cantor AB, Scuto A, Li C, Zhang S, et al: Prediction of radiation sensitivity using a gene expression classifier. Cancer Res 65: 7169-7176, 2005.

29. Zheng L, Tang W, Wei F, Wang H, Liu J, Lu Y, Cheng Y, Bai X, Yu X and Zhao W: Radiation-inducible protein RbAp48 contributes to radiosensitivity of cervical cancer cells. Gynecol Oncol 130: 601-608, 2013.

30. Kong L, Yu XP, Bai XH, Zhang WF, Zhang Y, Zhao WM, Jia JH, Tang W, Zhou YB and Liu CJ: RbAp48 is a critical mediator controlling the transforming activity of human papillomavirus type 16 in cervical cancer. J Biol Chem 282: 26381-26391, 2007. 
31. Teyssier F, Bay JO, Dionet C and Verrelle P: Cell cycle regulation after exposure to ionizing radiation. Bull Cancer 86: 345-357, 1999.

32. Iliakis G, Wang Y, Guan J and Wang H: DNA damage checkpoint control in cells exposed to ionizing radiation. Oncogene 22: 5834-5847, 2003.

33. Miyata H, Doki Y, Yamamoto $\mathrm{H}$, Kishi $\mathrm{K}$, Takemoto $\mathrm{H}$, Fujiwara Y, Yasuda T, Yano M, Inoue M, Shiozaki H, et al: Overexpression of CDC25B overrides radiation-induced G2-M arrest and results in increased apoptosis in esophageal cancer cells. Cancer Res 61: 3188-3193, 2001.

34. Bulavin DV, Higashimoto Y, Popoff IJ, Gaarde WA, Basrur V, Potapova O, Appella E and Fornace AJ Jr: Initiation of a G2/M checkpoint after ultraviolet radiation requires p38 kinase. Nature 411: 102-107, 2001.

35. Jin P, Gu Y and Morgan DO: Role of inhibitory CDC2 phosphorylation in radiation-induced G2 arrest in human cells. J Cell Biol 134: 963-970, 1996.

36. Kao GD, McKenna WG, Maity A, Blank K and Muschel RJ Cyclin B1 availability is a rate-limiting component of the radiation-induced G2 delay in HeLa cells. Cancer Res 57: 753-758, 1997.

37. Maity A, McKenna WG and Muschel RJ: Evidence for post-transcriptional regulation of cyclin B1 mRNA in the cell cycle and following irradiation in HeLa cells. EMBO J 14: 603-609, 1995.

38. Porter LA, Singh G and Lee JM: Abundance of cyclin B1 regulates gamma-radiation-induced apoptosis. Blood 95: 2645-2650, 2000.

39. Sui X, Cai J, Li H, He C, Zhou C, Dong Y, Chen L, Zhang B, Wang Y, Zhang Y, et al: p53-dependent CD51 expression contributes to characteristics of cancer stem cells in prostate cancer. Cell Death Dis 9: 523, 2018.

40. Pérez-Yépez EA, Saldívar-Cerón HI, Villamar-Cruz O, Pérez-Plasencia $\mathrm{C}$ and Arias-Romero LE: p21 Activated kinase 1: Nuclear activity and its role during DNA damage repair. DNA Repair (Amst) 65: 42-46, 2018

41. Galanos P, Pappas G, Polyzos A, Kotsinas A, Svolaki I, Giakoumakis NN, Glytsou C, Pateras IS, Swain U, Souliotis VL, et al: Mutational signatures reveal the role of RAD52 in p53-independent p21-driven genomic instability. Genome Biol 19: 37, 2018.

42. Wang Y, Qiu C, Lu N, Liu Z, Jin C, Sun C, Bu H, Yu H, Dongol S and Kong B: FOXD1 is targeted by miR-30a-5p and miR-200a-5p and suppresses the proliferation of human ovarian carcinoma cells by promoting $\mathrm{p} 21$ expression in a p53-independent manner. Int J Oncol 52: 2130-2142, 2018

43. Kim KW, Moretti L, Mitchell LR, Jung DK and Lu B: Endoplasmic reticulum stress mediates radiation-induced autophagy by perk-eIF2alpha in caspase-3/7-deficient cells Oncogene 29: 3241-3251, 2010

44. Kuida K, Haydar TF, Kuan CY, Gu Y, Taya C, Karasuyama H, Su MS, Rakic P and Flavell RA: Reduced apoptosis and cytochrome c-mediated caspase activation in mice lacking caspase 9. Cell 94: 325-337, 1998.

45. Franke TF, Kaplan DR and Cantley LC: PI3K: Downstream AKTion blocks apoptosis. Cell 88: 435-437, 1997.

46. Larue L and Bellacosa A: Epithelial-mesenchymal transition in development and cancer: Role of phosphatidylinositol 3 kinase/AKT pathways. Oncogene 24: 7443-7454, 2005.
47. Sun G, Wang X, Li T, Qu S and Sun J: Taurine attenuates acrylamide-induced apoptosis via a PI3K/AKT-dependent manner. Hum Exp Toxicol: Jan 1, 2018 (Epub ahead of print).

48. Weng HY, Hsu MJ, Wang CC, Chen BC, Hong CY, Chen MC, Chiu WT and Lin CH: Zerumbone suppresses IKKa, Akt, and FOXO1 activation, resulting in apoptosis of GBM 8401 cells. J Biomed Sci 19: 86, 2012.

49. Wu DD, Gao YR, Li T, Wang DY, Lu D, Liu SY, Hong Y, Ning HB, Liu JP, Shang J, et al: PEST-containing nuclear protein mediates the proliferation, migration, and invasion of human neuroblastoma cells through MAPK and PI3K/AKT/mTOR signaling pathways. BMC Cancer 18: 499, 2018.

50. Kwon MJ and Nam TJ: A polysaccharide of the marine alga Capsosiphon fulvescens induces apoptosis in AGS gastric cancer cells via an IGF-IR-mediated PI3K/Akt pathway. Cell Biol Int 31: 768-775, 2007

51. Li D, Qu X, Hou K, Zhang Y, Dong Q, Teng Y, Zhang J and Liu Y: PI3K/Akt is involved in bufalin-induced apoptosis in gastric cancer cells. Anticancer Drugs 20: 59-64, 2009.

52. Lukoseviciene V, Tikuisis R, Dulskas A, Miliauskas P and Ostapenko V: Surgery for triple-negative breast cancer-does the type of anaesthesia have an influence on oxidative stress, inflammation, molecular regulators, and outcomes of disease? J BUON 23: 290-295, 2018.

53. Wei X, Liu M, Ding Y, Li Q, Cheng C, Zong X, Yin W, Chen J and $\mathrm{Gu}$ W: Setup errors and effectiveness of Optical Laser 3D Surface imaging system (Sentinel) in postoperative radiotherapy of breast cancer. Sci Rep 8: 7270, 2018.

54. Wang Y, Xu H, Liu T, Huang M, Butter PP, Li C, Zhang L, Kao GD, Gong Y, Maity A, et al: Temporal DNA-PK activation drives genomic instability and therapy resistance in glioma stem cells. JCI Insight 3: pii: 98096, 2018.

55. Zhou P, Li B, Liu F, Zhang M, Wang Q, Liu Y, Yao Y and Li D: The epithelial to mesenchymal transition (EMT) and cancer stem cells: Implication for treatment resistance in pancreatic cancer. Mol Cancer 16: 52, 2017.

56. Tang X, Hu YJ, Ju WT, Fu Y, Sun WW, Liu Y, Tan YR, Wang LZ Li J, Tu YY, et al: Elevated growth differentiating factor 15 expression predicts long-term benefit of docetaxel, cisplatin and 5-fluorouracil induction chemotherapy in patients with oral cancer. Oncol Lett 15: 8118-8124, 2018.

57. Uitterhoeve AL, Koolen MG, van Os RM, Koedooder K, van de Kar M, Pieters BR and Koning CC: Accelerated high-dose radiotherapy alone or combined with either concomitant or sequential chemotherapy; treatments of choice in patients with non-small cell lung cancer. Radiat Oncol 2: 27, 2007.

This work is licensed under a Creative Commons Attribution-NonCommercial-NoDerivatives 4.0 International (CC BY-NC-ND 4.0) License. 